\title{
DUKUNGAN SOSIAL ORANGTUA TEHADAP ATLET PARALIMPIK PELAJAR TUNA NETRA BERPRESTASI DI KOTA BANDUNG
}

\author{
Oleh: \\ Aditya Rahmat Gunawan, Binahayati Rusyidi, \& Lenny Meilany \\ Email: \\ rahmatgunawanaditya@gmail.com
}

\begin{abstract}
ABSTRAK
Atlet paralimpik pelajar tuna netra adalah seorang penyandang tuna netra yang memiliki potensi dalam bidang olahraga dan memilih menjadi seorang atlet yang tergabung ke dalam naungan National Paralympic Committee Indonesia (NPCI). Di Kota Bandung sendiri, terdapat 11 orang anak penyandang tuna netra yang tergabung menjadi atlet binaan NPCI Kota Bandung. Beragam prestasi pernah mereka dapatkan. Dari lima kali gelaran Pekan Paralimpik Pelajar Daerah (Peparpelda) Jawa Barat, kontingen Kota Bandung berhasil tiga kali merebut predikat sebagai juara umum, dan dua kali menjadi runner-up. Prestasi yang didapatkan tentunya tidak hanya ditentukan oleh faktor fisik seorang atlet saja, akan tetapi terdapat beberapa faktor lain yang mendukung dan menunjang pencapaian prestasi seorang atlet paralimpik pelajar tuna netra. Salah satu faktor yang paling penting dan harus didapatkan oleh para atlet adalah dukungan sosial dari kedua orangtuanya. Karena, orangtua selaku lingkungan sosial pertama yang dimiliki oleh seseorang, memiliki kewajiban untuk memenuhi kebutuhan dasar seorang anak, baik dari segi kebutuhan dasar psikis, fisik, dan sosialnya. Dengan terpenuhinya dukungan yang diberikan oleh orangtua terhadap anak, maka akan memunculkan perasaan aman, nayaman, dihargai, dan mendapatkan kasih sayang. Hal ini terkait dengan bentukbentuk dukungan sosial yang diberikan oleh orang tua terhadap para atlet paralimpik pelajar tuna netra berprestasi di Kota Bandung. Bentuk-bentuk dukungan sosial yang dimaksud adalah dukungan instrumental, dukungan emosional, dukungan informasional, dan dukungan penghargaan. Di tengah stigma negatif yang diterima oleh para penyandang tuna netra, maka dukungan sosial dari orangtua diharapkan memberikan sebuah manfaat secara moril bagi mereka untuk menjalani hidup, dan bahkan bisa berprestasi di bidang-bidang sesuai dengan minat dan bakatnya.
\end{abstract}

Kata Kunci: Atlet paralimpik pelajar, tuna netra, dukungan sosial orangtua.

\section{ABSTRACT}

Blind student paralympic athletes is a blind persons who have potential in the field of sports and chose to become an athlete belonging to the auspices of the National Paralympic Committee of Indonesia (NPCI). In Bandung, there are 11 children with visual impairment is incorporated into the built athlete NPCI Bandung. Diverse achievement once they get. From five times the mat Paralympic Regional Student Week (Peparpelda), West Java, Bandung contingent successfully three times to seize the title as overall champion and twice as a runner-up. Achievement of course obtained not only determined by the physical factors of an athlete, but also there are some other factors that favor and 
support the achievement of an athlete Paralympic blind students. One of the most important factors and must be obtained by the athletes is social support from both parents. Because, parents as the first social environment that is owned by someone, have an obligation to meet the basic needs of a child, both in terms of basic needs psychological, physical, and social. With the fulfillment of the support provided by the parent to the child, it will bring a feeling of safety, nayaman, valued, and receive affection. It is associated with other forms of social support given by parents for Paralympic athletes blind students excel in Bandung. Forms of social support in question is instrumental support, emotional support, informational support, and support award. In the midst of the negative stigma that is received by the blind persons, the social support of parents expected to provide a benefit for them to live a moral life, and can even excel in fields according to their interests and talents.

Keywords: Student paralympic athletes, blind, parents social support

\section{PENDAHULUAN}

Indonesia saat ini tercatat sebagai salah satu negara dengan jumlah penyandang disabilitas terbesar di Asia. Berdasarkan data yang dikeluarkan oleh Kementerian Sosial RI pada tahun 2013, jumlah penyandang disabilitas berat di Indonesia tercatat sebesar 3.342.303 jiwa. Sementara, data yang dikeluarkan oleh PT. Surveyor Indonesia (Persero) menyatakan bahwa jumlah penyandang disabilitas di Indonesia berjumlah 4.783.267 jiwa. Jumlah tersebut terbagi dari empat kategori kecacatan yaitu, sebanyak 1.749.981 jiwa sebagai penyandang tuna netra, 602.784 jiwa penyandang tuna wicara/rungu, 1.652.741 penyandang tuna daksa, dan 777.761 jiwa penyandang tuna grahita. Berdasarkan data tersebut, Jawa Barat tercatat sebagai provinsi dengan populasi penyandang disabilitas terbanyak di Indonesia dengan presentase $50,90 \%$.

Jika mengacu kepada data yang dikeluarkan oleh Badan Pusat Statistik (BPS) pada tahun 2010, jumlah penduduk Provinsi Jawa Barat yang mengalami kesulitan penglihatan parah berjumlah sebanyak 85.438 jiwa, dan sedikit kesulitan penglihatan berjumlah 975.550 jiwa. Dan dari jumlah tersebut, sebanyak 62.446 jiwa yang mengalami kesulitan penglihatan parah dan 4.771 jiwa mengalami sedikit kesulitan penglihatan berada di Kota Bandung. Dari ribuan penyandang tuna netra di Kota Bandung, yang terdiri dari berbagai kelompok umur, terdapat para penyandang tuna netra pelajar yang memilih untuk menjadi seorang atlet paralimpik. Sebuah pilihan yang tentunya sangat luar biasa, dimana ketika keterbatasan bukanlah menjadi sebuah halangan bagi para penyandang tuna netra untuk berprestasi di bidang olahraga. Berdasarkan data yang ditemukan, terdapat 11 pelajar tuna netra di Kota Bandung yang terdaftar sebagai atlet paralimpik binaan dari National Paralympic Committee Indonesia (NPCI) Kota Bandung. Jumlah tersebut, belum termasuk para atlet paralympic yang belum bergabung menjadi atlet binaan NPCI Kota Bandung.

Kontingen atlet paralympic Kota Bandung tercatat memiliki beberapa prestasi di antaranya, dari lima kali gelaran Pekan Paralimpik Pelajar Daerah (Peparpelda) Jawa Barat, Kota Bandung berhasil menjadi juara umum sebanyak tiga kali, dan dua kali menjadi runner up.

Tuna netra adalah sebuah kondisi dimana seseorang memiliki keterbatasan penglihatan, yang dapat disebabkan oleh faktor internal dan eksternal individu. Menurut Sutjihati (2006), Faktor internal yang dapat menyebabkan ketunanetraan adalah karena faktor gen (keturunan), kekurangan gizi, kondisi psikis ibu pada saat hamil, keracunan obat, dan sebagainya. Sementara faktor eksternal yang dapat menyebabkan ketunanetraan adalah karena kecelakaan, peradangan mata karena penyakit, pengaruh alat bantu medis pada waktu melahirkan yang 
menyebabkan sistem persyarafannya rusak, dan lain-lain. Pengertian tuna netra tidak saja mereka yang buta, akan tetapi mencakup juga mereka yang mampu melihat tetapi terbatas dan kurang dapat dimanfaatkan untuk kepentingan hidup sehari-hari. Sehingga, berdasarkan penjelasan tersebut, maka terdapat dua macam kelompok ketunanetraan yaitu, buta total, dan low vision.

Secara umum, ketunanetraan seringkali membawa penyandangnya pada keterbatasan kemampuan berorientasi pada lingkungannya. Keterbatasan ini seringkali menimbulkan rasa kecewa, perasaan mudah tersinggung, menjadi lebih emosional dan berpotensi menyebabkan masalah kejiwaan seperti pesimistis, cuek, atau masa bodoh, putus asa bahkan rendah diri. Halhal seperti inilah yang sering menjadi permasalahan sosial bagi penyandang tuna netra. dalam kondisi seperti tu, maka para penyandang tuna netra sangat membutuhkan sumber daya sosial atau manusia dari lingkungan fisik tedekat yaitu keluarga, terutama kedua orang tua.

Dalam tahap perkembangannya, seseorang dengan tuna netra tentunya memiliki perbedaan jika dibandingkan dengan anakanak lainnya. Selain dihadapkan dengan kondisi fisik yang berbeda, para penyandang tuna netra pun dihadapkan dengan masalahmasalah di tengah masyarakat yang akan mempengaruhi tumbuh kembangnya. Masalah-masalah yang umunya dialami oleh para penyandang tuna netra adalah penerimaan dari orang tua, anggota keluarga lain, dan masyarakat. Selain masalah penerimaan, para penyandang tuna netra juga kerap kali menerima pandangan negatif, dan didiskriminasi. Padahal, meskipun secara fisik berbeda, seharusnya seorang dengan tuna netra tetap mendapatkan perlakuan yang sama baik dari keluarga, maupun dari lingkungan masyarakat.

Pada tahap perkembangan anak dan remaja yang tergolong ke dalam kategori pelajar, tentunya membutuhkan sebuah penerimaan dan dukungan yang begitu besar dari lingkungan sosialnya. Karena, dengan keterbatasan dan kondisi fisik yang berbeda, para pelajar tuna netra sering kali mendapatkan perlakuan-perlakuan yang tidak sesuai. Secara fakta, memang benar adanya penderita tuna netra yang memasuki usia remaja memerlukan pendidikan dan pelayanan yang khusus dari keluarga atau suatu lembaga terkait agar mereka dapat mengembangkan dirinya sesuai dengan kapasitas kemampuan dan cita-cita yang dimiliki. Karena di saat seseorang didukung oleh lingkungan, maka segalanya akan terasa lebih mudah. Karena dukungan sosial yang diterima dapat membuat individu merasa lebih tenang, merasa diperhatikan, dicintai, dan timbul rasa percaya diri dan kompeten. Selain itu, dukungan sosial sangat diperlukan oleh siapapun dalam berhubungan dengan orang lain demi melangsungkan hidupnya di tengah masyarakat. Keberfungsian sosial remaja tuna netra akan perkembangan kepribadian potensi yang dimilikinya diperkuat oleh adanya suatu dukungan yang berasal dari lingkungan terdekatnya yaitu kedua orangtua.

Dukungan paling fundamental yang seharusnya didapatkan oleh penyandang tuna netra berasal dari dukungan sosial orang tua. Oleh karena itu, orang tua memiliki peran yang sangat penting dalam proses perkembangan penyandang tuna netra. Orang tua menjadi lingkungan yang pertama kali merasakan dampak dari ketunanetraan. Bentuk penerimaan yang ditunjukan oleh orang tua akan sangat berpengaruh terhadap keseluruhan perkembangan kepribadian anak di kemudian hari.

Dukungan sosial yang diberikan oleh orang tua, pada dasarnya memiliki peran untuk memenuhi kebutuhan anggota keluarganya, baik dari segi materi hingga moril. Sehingga, dukungan sosial yang diberikan, dapat memberikan sebuah kepercayaan diri, motivasi, kenyamanan, dan kesejahteraan bagi setiap anggota keluarga. Orang tua atau ayah dan ibu selaku orang pertama yang mengenal diri seorang anak, tentunya memiliki peran yang sangat penting dalam memenuhi kebutuhan fisik, psikis, emosional dan sosial 
anak. Bentuk pemenuhan kebutuhan fisik seperti makan, minum, pakaian, dan lain-lain, serta pemberian sebuah penghargaan, kasih sayang, dan informasi, menjadi sebuah contoh bentuk dukungan sosial yang diberikan oleh orang tua terhadap anaknya. Dampak dari diberikannya dukungan sosial terhadap anak, akan mencipatkan sebuah kondisi dimana anak merasa memiliki harga diri, dicintai, serta kepercayaan diri yang kuat.

Dukungan sosial orangtua diartikan sebagai sebuah bentuk pemberian dukungan emosional, instrumental, penghargaan, dan informasi, dengan tujuan memberikan sebuah pemenuhan kebutuhan terhadap anak, agar anak mampu tumbuh dengan baik, dan memiliki kerpibadian yang positif, yang disertai dengan rasa aman, percaya diri, dan dimiliki oleh orang lain. Hal ini sejalan dengan yang dikemukakan oleh Sarafino (1994) yang menyatakan bahwa dukungan sosial yaitu bentuk penerimaan dari seseorang atau sekelompok orang terhadap individu yang menimbulkan persepsi dalam dirinya bahwa ia disayangi, diperhatikan, dihargai, dan ditolong. Kondisi-kondisi seperti merasa dihargai, disayangi, diperhatikan, dan dimiliki, adalah sebuah hasil yang diawali dengan pemberian bentuk-bentuk dukungan sosial. Bentuk-bentuk dukungan sosial yang dimaksud adalah, dukungan emosional, dukungan instrumental, dukungan penghargaan, dan dukungan informasional. Pendapat lain mengenai dukungan sosial menurut Cohen dalam Borgotta (1992:1976), dimaknai sebagai "suatu bentuk hubungan sosial yang bersifat menolong dan membantu individu dalam menghadapi suatu kejadian yang menekankan atau mengalami kesulitan yang melibatkan aspek antara lain: emosional dan instrumental". Selain itu, pemenuhan dukungan sosial akan memberikan pengaruh positif bagi terbangunnya sikap dan kemampuan adaptif seseorang dalam merespon situasi yang dialami. Kemudian, lambat laun seseorang sudah akan lebih mudah berinteraksi dengan lingkungannya bahkan akan dapat mengembangkan potensi yang ada dalam dirinya.
Bagi para penyandang tuna netra yang menjadi atlet paralimpik pelajar, dukungan sosial orang tua yang diberikan, menjadi salah satu faktor non-teknis yang diharapkan mampu berkontribusi terhadap pencapaian prestasi para tuna netra. Dalam mencapai sebuah prestasi, tentunya atlet tidak hanya ditunjang oleh keterampilan berolahraganya saja. Selain keterampilan secara fisik dan psikis, prestasi atlet juga sangat dipengaruhi oleh faktor dukungan sosial yang diberikan oleh lingkungan terdekatnya seperti keluarga, teman sebaya, pelatih, dan lain-lain. Orang tua yang menjadi lingkungan pertama dan paling mengenal kondisi seorang anak, menjadi elemen terpenting dalam memberikan dukungan. Dukungan sosial yang diberikan oleh keluarga terutama ayah dan ibu, akan meningkatkan motivasi atlet untuk lebih berprestasi. Seperti yang diungkapkan oleh Myers (2010), menyatakan bahwa dukungan sosial dapat diperoleh oleh dari orang-orang yang memiliki hubungan dekat dengan individu seperti sanak keluarga, teman, atau anggota organisasi. Namun menurut Rodin \& Salovey (dalam Smet, 1994) dukungan sosial yang terpenting adalah dari keluarga.

Mengingat pentingnya dukungan sosial yang diberikan oleh orang tua, maka peneliti mencoba untuk menggambarkan bentukbentuk dukungan sosial yang diberikan kepada para atlet paralimpik pelajar tuna netra di Kota Bandung. Bentuk-bentuk dukungan sosial orang tua yang dimaksud adalah berupa dukungan emosional, instrumental, penghargaan, dan informasi.

\section{PEMBAHASAN}

Dalam mencapai sebuah prestasi, atlet paralympic pelajar di Kota Bandung tentunya memiliki beberapa faktor pendorong yang dapat memacu pencapaiannya tersebut. Salah satu faktornya adalah dukungan yang diberikan oleh orangtua. Hal ini dikarenakan dukungan orangtua menjadi sumber dukungan utama dalam kehidupan seseorang, dan sangat mempengaruhi pencapaian tujuan-tujuan 
dalam kehidupan.Bentuk dukungan sosial orangtua yang diberikan kepada atlet paralympic pelajar bisa berupa dukungan emosional, dukungan penghargaan, dukungan instrumental, dan dukungan informasi. Semakin besar atau maksimalnya bentukbentuk dukungan tersebut diberikan, maka akan tumbuh kepribadian yang lebih baik jika dibandingkan dengan individu yang tidak mendapatkan dukungan sosial dengan baik.

Beragam prestasi yang berhasil didapatkan oleh para atlet paralympic pelajar di Kota Bandung, tentunya bukanlah hal mudah. Dengan segala keterbatasan yang dimiliki, para atlet mampu menunjukan kemampuannya dan mampu mencapai prestasi yang membanggakan kedua orangtuanya. Maksimalnya performa para atlet, tidak dapat dilepaskan dari faktor psikis dan sosial atlet. Kenyamanan, kepercayaan diri, dan rasa berharga yang timbul dari dukungan orangtua, membentuk kondisi-kondisi tersebut. Maka dari itu, begitu pentingnya sebuah dukungan yang diberikan oleh orangtua, sehingga para atlet bisa berprestasi.

Manusia sebagai makhluk sosial dalam menghadapi dan menjalani kehidupannya memerlukan bantuan dan dukungan sosial dari orang-orang di sekitarnya untuk membantu menghadapi berbagai masalah. Hal tersebut tentunya tidak terlepas dari hasil interaksi antar manusia dimana kemudian akan timbul perasaan saling membutuhkan satu sama lainnya yang termasuk ke dalam kebutuhan mereka akan dukungan sosial.

Dukungan sosial terdiri informasi verbal atau non-verbal atau nasehat, bantuan yang nyata atau terlihat, atau tingkah laku yang diberikan oleh orang-orang yang akrab dengan subjek di dalam lingkungan sosialnya dan halhal yang dapat memberikan keuntungan emosional atau berpengaruh pada tingkah laku penerimanya. Dalam hal ini orang yang merasa memperoleh dukungan sosial, secara emosional merasa lega karena diperhatikan, mendapat saran atau kesan yang menyenangkan pada dirinya.
Definisi lain juga dikemukakan oleh Taylor (dalam Inne, 2014) yang mengatakan bahwa dukungan sosial merupakan bentuk pemberian informasi serta merasa dirinya dicintai dan diperhatikan, terhormat dan dihargai, serta merupakan bagian dari jaringan komunikasi dan kewajiban timbal balik dari orang tua, kekasih, kerabat, teman, jaringan lingkungan sosial serta dalam lingkungan masyarakat. Kemudian Sarason (2001) mengatakan bahwa dukungan sosial adalah keberadaan, kesediaan, kepedulian dari orangorang yang dapat diandalkan, menghargai dan menyayangi kita.

$$
\text { Selanjutnya Sarafino }
$$

menyatakan bahwa dukungan sosial yaitu bentuk penerimaan dari seseorang atau sekelompok orang terhadap individu yang menimbulkan persepsi dalam dirinya bahwa ia disayangi, diperhatikan, dihargai, dan ditolong. Di samping itu, (Etzion dalam Inne, 2014) mengartikan dukungan sosial sebagai hubungan antar pribadi yang di dalamnya terdapat satu atau lebih ciri-ciri, antara lain: bantuan atau pertolongan dalam bantuan fisik, perhatian emosional, pemberian informasi dan pujian.

Berdasarkan pada definisi dukungan sosial beberapa ahli yang telah dikemukakan di atas, dapat ditarik kesimpulan bahwa dukungan sosial merupakan dukungan yang diberikan oleh orang-orang yang berada di sekitar individu dimana hasil dari pemberian dukungan tersebut mampu membuat individu merasa nyaman baik secara fisik maupun psikologis dan sebagai bukti bahwa mereka diperhatikan dan dicintai. Semua manusia pada dasarnya membutuhkan dukungan sosial. Dukungan sosial sendiri memberikan manfaat positif terhadap penerima ketika dukungan sosial yang diberikan tepat sesuai dengan harapan orang yang membutukan dukungan tersebut. Oleh karena itu, diperlukan suatu pemahaman yang baik antara pemberi (pereceiver) dan penerima (receiver) dukungan. Dukungan sosial bukan hanya sekedar memberikan bantuan, tetapi yang terpenting adalah bagaimana persepsi dari 
penerima terhadap makna dari bantuan tersebut.

Di Matteo (1991) mengatakan bahwa dukungan sosial dapat diperoleh dari keluarga, teman, tetangga, dan rekan kerja. Pendapat hampir senada pula disebutkan oleh Sarafino (1990) bahwa dukungan sosial dapat diperoleh dari berbagai macam sumber seperti suami, istri, keluarga, teman kerja, dan organisasi kemasyarakatan. Selanjutnya Caplan (Alan Vaux, 1988) mengatakan bahwa dukungan sosial dapat diperoleh dari pasangan hidup, kekasih, keluarga, teman kerja, atau organisasi kemasyarakatan yang diikuti. Semakin dekat hubungan pemberi dengan penerima dukungan, makan akan semakin kuat dampak dukungan yang dirasakan.

Fungsi dari dukungan sosial orangtua sendiri bagi remaja yaitu dapat memberikan penguatan positif terhadap mereka, yaitu dalam menumbuhkan rasa aman dalam melakukan partisipasi aktif dan eksplorasi dalam kehidupan yang pada akhirnya menumbuhkan peningkatan rasa percaya diri pada rermaja untuk menghadapi situasi baru dan tantangan dalam kehidupannya. Wills dan Clearly (1996) menjelaskan bahwa dukungan orangtua tidak hanya mencegah atau mengurangi gejala stres remaja, tetapi juga dapat meingkatkan efek dari faktor-faktor protektif yang membangun seperti akademis.

\section{KESIMPULAN}

Dukungan sosial yang diberikan oleh orangtua terhadap para atlet paralimpik tuna netra, pada dasarnya memiliki tujuan untuk meberikan pemenuhan kebutuhan dasar bagi seorang anak. Kebutuhan-kebutuhan tersebut meliputi kebutuhan emosional, instrumental, penghargaan, dan informasional. Manfaat dari pemberian bentuk-bentuk dukungan sosial tersebut, dapat menciptakan sebuah kondisi rasa aman, nyaman, dihargai, dicintai, dan kasih sayang. Sehingga, seorang anak dengan tuna netra yang menjadi seorang atlet paralimpik mampu mengembangkan potensinya dengan baik. Hal ini dikarenakan, dengan maksimalnya dukungan sosial yang diberikan, maka akan menciptakan kondisi psikis, dan sosial seorang anak yang baik.

Dalam kaitannya dengan ppencapaian seorang atlet, seorang atlet memiliki beberapa faktor yang dapat menunjang pencapaian prestasinya. Pada faktor-faktor yang mempengaruhi pencapaian seorang atlet, terdapat beberapa faktor yang terbagi menjadi faktor endogen seseorang dan faktor eksogen. Pada faktor endogen, terdapat faktor psikologis yang mempengaruhi pencapaian seorang atlet. Salah satu lingkungan yang dapat menjamin baik atau tidaknya kondisi psikologis seseorang adalah kedua orangtua. Dengan maksimalnya dukungan sosial yang diberikan , maka akan meningkatkan kondisi psikologis dan motivasi seorang atlet yang sangat dibutuhkan.

Jika dilihat pada faktor-faktor eksogen yang mempengaruhi prestasi seoran anak, peran keluarga terutama orang tua terlihat begitu sentral. Baik hubungan emosional antara anak dan orang tua, kondisi ekonomi keluarga, dan cara mendidik anak, adalah gambaran akan pentingnya dukungan sosial orang tua bagi anak. Terutama, para atlet paralimpik pelajar tuna netra.

Dengan diberikannya dukungan emosional yang baik oleh orang tua, maka akan menciptakan sebuah hubungan emosional yang baik dengan anak. Selain itu, kondisi ekonomi keluarga pun mempengaruhi pencapaian prestasi atlet. Kondisi ekonomi keluarga yang terkait dengan bentuk pemberian dukungan instrumental, akan berfungsi untuk memberikan dukungan dari segi materil bagi anak.

Hal ini memberikan gambaran, bahwa dalam pencapaian prestasi seorang atlet, tidak hanya ditentukan oleh faktor keterampilan fisiknya saja. Akan tetapi, faktor psikologis dan sosial memberikan peran yang lebih banyak bagi seorang anak dengan tuna netra. Semakin maksimal pemberian dukungan sosial yang diberikan oleh orang tua, maka akan menciptakan sebuah kondisi psikologis dan 
sosial yang lebih baik, sehingga akan meningkatkan peluang seorang atlet paralimpik pelajar tuna netra untuk lebih berprestasi.

\section{DAFTAR PUSTAKA}

Bellini, J.L. \& Rumrill, P. D., Jr. 1999. Research in Rehabilitation Counseling. Springfield, Illinois: Charles C Thomas Publisher, Ltd.

Ben-Zur, H. \& Debi, Z. 2005. Optimism, Social Comparisons, and Coping with Vision Loss in Israel. Journal of Visual Impairment and Blindness, 99 (3), 151-164.

Dodds, A. 1993. Rehabilitating Blind and Visually Impaired People: A Psychological Approach. London: Chapman \& Hall.

Gottlieb, H. Benjamin. 1983. Social Support Strategies, USA: Sage Publication Ltd.

Hallahan, D. P. \& Kauffman, J.M. 1991. Exceptional Children-Introduction to Special Education. Virginia: Prenticehall International, Inc.

Munandar, Utami. 2004. Pengembangan Kreativitas Anak Berbakat, Jakarta: Rineka Cipta
Sarafino, Edward P, 1990, Health Psychology and Psychosicial Interaction, Canada: John Willey \& Sons, Inc.

Somantri, T. Sutjihati, 2006, Psikologi Anak Luar Biasa, PT. Refika Aditama, Bandung.

Sugiyono. 2009. Memahami Penelitian Kualitatif. Bandung : Alfabeta.

Jurnal, "Hubungan Dukungan Sosial Orang Tua, Pelatih, dan Teman dengan Motivasi Berprestasi Akademik dan Motivasi Berprestasi Olahraga (Basket) pada Mahasiswa Atlet Basket Universitas Surabaya", Elita Perwira Putri, 2014

http://www.npcindonesia.org/klasifikasi/

http://definisipengertian.com/2012/pengertian -definisi-prestasi-menurut-para-ahli/

http://www.kartunet.or.id/simpang-siurpopulasi-disabilitas-di-indonesia$1295 /$

http://sp2010.bps.go.id/index.php/site/tabel?ti $\mathrm{d}=273 \&$ wid $=3200000000$

http://sp2010.bps.go.id/index.php/site/tabel?ti $\mathrm{d}=274 \&$ wid $=3200000000$ 